Danish Yearbook of Philosophy 


\section{Danish Yearbook of Philosophy}

\section{Editor-in-Chief}

Finn Collin, University of Copenhagen, Denmark

\section{Managing Editor}

Asger Sørensen, Aarhus University, Denmark

Book Review Editor

Mogens Chrom Jacobsen, Independent scholar

\section{Young Scholars Editors}

Lasse Nielsen, Southern Danish University

Mads Peter Karlsen, Copenhagen Business School

Editorial board

Dorthe Jørgensen, Aarhus University

Esther Oluffa Pedersen, Roskilde University

Henrik Jøker Bjerre, Aalborg University

Merete Wiberg, Aarhus University

Lasse Nielsen, Southern Danish University

Mads Peter Karlsen, Copenhagen Business School

Klemens Kappel, University of Copenhagen

\section{International Editorial Board}

Daniel Gamper Sachse, Universitat Autònoma de Barcelona

David Rasmussen, Boston College

Mogens Lærke, École normale supérieure de Lyon

Gerhard Schweppenhäuser, Hochschule für angewandte Wissenschaften Würzburg-Schweinfurt

Gunnar Skirbekk, University of Bergen

Hans Ruin, Södertörn University

Robert A. Stern, University of Sheffield

Volumes published in this journal are listed at brill.com/dyp 


\title{
Danish Yearbook of Philosophy
}

VOLUME 54 (2021)

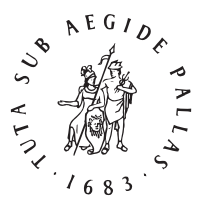 \\ B R I L L \\ LEIDEN | BOSTON
}




\section{Online Submission}

Danish Yearbook of Philosophy uses Editorial Manager, a web-based submission and peer review tracking system. All manuscripts should therefore be submitted online at www.editorialmanager.com/dyp. Please make sure to consult the Instructions to Authors prior to submission to ensure your submission is formatted correctly. For any questions, please contact the Editorial Office at collin@hum.ku.dk.

Brill Open Access options can be found at brill.com/openaccess.

Typeface for the Latin, Greek, and Cyrillic scripts: "Brill”. See and download: brill.com/brill-typeface.

ISSN $0070-2749$

E-ISSN 2468-9300

Copyright 2021 by Koninklijke Brill NV, Leiden, The Netherlands.

Koninklijke Brill NV incorporates the imprints Brill, Brill Nijhoff, Brill Hotei, Brill Schöningh, Brill Fink, Brill mentis, Vandenhoeck \& Ruprecht, Böhlau Verlag and V\&R Unipress.

All rights reserved. No part of this publication may be reproduced, translated, stored in a retrieval system, or transmitted in any form or by any means, electronic, mechanical, photocopying, recording or otherwise, without prior written permission from the publisher. Requests for re-use and/or translations must be addressed to Koninklijke Brill NV via brill.com or copyright.com.

Brill has made all reasonable efforts to trace all rights holders to any copyrighted material used in this work. In cases where these efforts have not been successful the publisher welcomes communications from copyright holders, so that the appropriate acknowledgements can be made in future editions, and to settle other permission matters.

This journal is printed on acid-free paper and produced in a sustainable manner. 